\title{
Isolation of Exonuclease VIII: The Enzyme Associated with the sbcA Indirect Suppressor
}

\author{
(genetic recombination/Escherichia coli/recB/exonuclease V)
}

\author{
SIDNEY R. KUSHNER* ${ }^{*}$, HARUKO NAGAISHI $\ddagger$ AND A. J. CLARK‡
}

* Department of Biochemistry, Stanford University School of Medicine, Stanford, California 94305; and $\ddagger$ Department of Molecular

Biology, University of California, Berkeley, Calif. 94720

Communicated by Robley C. Williams, July 1, 1974

\begin{abstract}
B and/or recC deficiency in Escherichia coli K-12 is indirectly suppressed by the presence of $\operatorname{sbc} A^{-}$ mutations. sbc $A^{-}$strains contain an increased level of an ATP-independent nuclease. Genetic and enzymatic tests indicate that this activity is not exonuclease III, exonuclease V (recB-recC nuclease), DNA polymerase I, or lambda exonuclease. This new enzyme (exonuclease VIII) has been purified 750 -fold and shows a striking preference for double-stranded DNA over heat-denatured DNA. It does not act endonucleoly tically on closed circular, single-stranded DNA as exonuclease $V$ does. It also lacks a 3 '-phosphatase function. Analysis on sodium dodecyl sulfate-polyacrylamide gels indicates that exonuclease VIII is not present in unsuppressed $\left(s b c A^{+}\right)$strains. It is thought that $s b c A$ determines some type of control function; the structural gene for exonuclease VIII is denoted by recE.
\end{abstract}

The observation that $\mathrm{recB} \mathrm{B}^{-}$and/or $\mathrm{rec} \mathrm{C}^{-}$mutants carried out residual levels of wild-type genetic recombination $(1,2)$ indicated that Escherichia coli might possess a pathway of genetic recombination that normally was repressed and did not involve the $\mathrm{recB}$ and $\mathrm{rec} C$ gene products. Analysis of $\mathrm{Rec}^{+}$ revertants from $r e c B^{-}$and/or $r e c C^{-}$strains showed that indirect suppression did occur from alterations at two distinct loci. These strains remained genotypically $\operatorname{recB}$ and/or $r e c C$ deficient but became recombination proficient. Barbour et al. showed that strains carrying $s b c A^{-}$mutations contained increased levels of an ATP-independent DNase (3). A second class of indirect suppressor, called $s b c B$, involved the loss of exonuclease I, an enzyme specific for single-stranded DNA (4). A more detailed analysis of strains carrying $r e c B^{-}$and $s b c B^{-}$ mutations led to the demonstration of an alternate pathway for carrying out genetic recombination in $E$. coli (5).

Because of difficulties encountered in mapping the $s b c A$ locus, attention was focused on the $s b c B$ type of indirect suppressor. However, the striking difference in the apparent mode of action of these two loci suggested the importance of a complete characterization of the ATP-independent nuclease that was apparently associated with $s b c A^{-}$alleles. Goldmark and Linn have shown that the $\operatorname{recB}-\mathrm{rec} C$ gene products form a single enzyme (exonuclease V), which, in the presence of ATP, exonucleolytically digests single- and double-stranded DNA (6). In addition, exonuclease V acts as an ATP-stimulated, single-stranded endonuclease and a DNA-dependent ATPase (6). If the ATP-independent nuclease found in $s b c A^{-}$strains

Abbreviations: $s b c$, suppressor of $\operatorname{recB}$ and $\operatorname{rec} C$; $\mathrm{NaDodSO}_{4}$, sodium dodecyl sulfate.

$\dagger$ Present address: Department of Biochemistry, University of Georgia, Athens, Ga. 30602. substitutes for exonuclease V, an analysis of its substrate specificity will provide an important clue into the function of the recB-recC gene products in vivo.

In this communication we show by genetic and enzymatic tests that the nuclease present in $s b c A^{-}$strains is not exonuclease III, exonuclease V, DNA polymerase I, or lambda exonuclease. Electrophoretic analysis of purified fractions suggests that this enzyme, which we call exonuclease VIII, does not exist in unsuppressed strains. In its partially purified form the enzyme preferentially digests double-stranded DNA over heat-denatured, single-stranded DNA. It is suggested that $s b c A$ is not the structural gene for exonuclease VIII, but determines some type of control function. The structural gene has been denoted by $\operatorname{rec} E$ (7).

\section{MATERIALS AND METHODS}

Strains. JC7693 and JC7722 are isogenic derivatives of a $\mathrm{Su}^{-}$parent (JC4693), which has been described elsewhere (8). Both strains are genotypically $\operatorname{recB21,} \operatorname{sbcB15}, \sup D^{+}, \operatorname{trp}^{-}$, and leu- (the trp and leu mutations are caused by amber corlons). In addition, JC7693 contains $s b c A 9$, which was obtained by mutagenesis with ethyl methane sulfonate (3). $\mathrm{J}(77722$ is the unmutagenized parent. The presence of $r e c B 21$ and $s b c B 15$ in both strains was tested genetically and enzymatically prior to exonuclease VIII purifications. BW9091 carries the $x \operatorname{th} A 1$ mutation inactivating exonuclease III (9).

Materials. Reagents were obtained from the following sources: carrier-free $\left[{ }^{32} \mathrm{P}\right] \mathrm{H}_{3} \mathrm{PO}_{4},\left[\right.$ methyl- $\left.{ }^{3} \mathrm{H}\right]$ thymidine, "Ultra Pure" $\left(\mathrm{NH}_{4}\right)_{2} \mathrm{SO}_{4}$, and streptomycin sulfate, Schwarz/ Mann; salmon sperm DNA, Calbiochem Corp.; calf-thymus DNA, Sigma Chemical Co.; egg-white lysozyme and micrococcal nuclease, Worthington Biochemical Corp.; Brij-58, Atlas Chemical Industries; Munktell 410 cellulose, Bio-Rad Corp.; and DE-52, Reeve Angel. Antiserum to $E$. coli DNA polymerase I was the gift of Dr. A. Kornberg. Antiserum to lambda exonuclease was obtained from Dr. John Little, and purified lambda exonuclease from Dr. A. D. Kaiser.

$E$. coli B DNA was labeled with ${ }^{32} \mathrm{PO}_{4}$ in M-70 supplemented medium (10) and extracted by the method of Marmur (11). ${ }^{3} \mathrm{H}$-labeled $E$. coli DNA was prepared by the method of Mahler (12). ${ }^{3} \mathrm{H}$-labeled M13 DNA was made by the procedure of Forsheit and Ray (13). ${ }^{32} \mathrm{P}$-labeled nicked DNA for exonuclease III phosphatase assays was prepared as described by Richardson and Kornberg (14). ${ }^{32} \mathrm{P}$ - or ${ }^{3} \mathrm{H}$-labeled DNA $(150 \mu \mathrm{M})$ was heated for $10 \mathrm{~min}$ at $100^{\circ}$ and quickly chilled to produce heat-denatured DNA. 
TABLE 1. Purification of exonuclease VIII from JC7722 $\left(s b c A^{+}\right)$and JC7693 (sbcA9)*

\begin{tabular}{|c|c|c|c|c|c|c|c|c|}
\hline \multirow[b]{2}{*}{ Fraction } & \multicolumn{4}{|c|}{ JC7693 } & \multicolumn{4}{|c|}{ JC7722 } \\
\hline & Units $/ \mathrm{ml}$ & $\begin{array}{c}\text { Protein } \\
(\mathrm{mg} / \mathrm{ml})\end{array}$ & $\begin{array}{l}\text { Specific } \\
\text { activity }\end{array}$ & $\begin{array}{c}\% \\
\text { Recovery }\end{array}$ & Units $/ \mathrm{ml}$ & $\begin{array}{l}\text { Protein } \\
(\mathrm{mg} / \mathrm{ml})\end{array}$ & $\begin{array}{l}\text { Specific } \\
\text { activity }\end{array}$ & $\begin{array}{c}\% \\
\text { Recovery }\end{array}$ \\
\hline Crude lysate (I) & 172 & 7.5 & 23 & 100 & 86 & 10.0 & 8.6 & 100 \\
\hline Crude supernatant (II) & 165 & 5.0 & 33 & 70 & 124 & 6.0 & 20.7 & 99 \\
\hline Streptomycin supernatant (III) & 148 & 2.7 & 55 & 70 & 101 & 2.3 & 44 & 96 \\
\hline Ammonium sulfate (IV) & 1,842 & 10.7 & 172 & 59 & 89 & 7.1 & 12.5 & 6 \\
\hline Concentrated DEAE-cellulose (V) & 12,345 & 10.7 & 1,154 & 11 & 41 & 3.0 & 13.7 & 0.05 \\
\hline DNA-cellulose (VI) & 874 & 0.05 & 17,480 & $\dagger$ & 一 & - & 一 & 一 \\
\hline
\end{tabular}

* Exonuclease VIII was purified from both strains as described in Materials and Methods.

† The DNA-cellulose column was run at a later date, and accurate recoveries were not determined.

DNA-cellulose was prepared by the method of Alberts (15). The calf-thymus DNA $(12 \mathrm{mg} / \mathrm{ml})$ was heated at $100^{\circ}$ for 15 min and rapidly chilled prior to binding to the cellulose.

Enzyme Assays. DNA polymerase I was assayed with activated calf-thymus DNA as substrate by the procedure of Richardson et al. (16). Exonuclease III phosphatase was determined as described by Richardson and Kornberg (14). The assay of lambda exonuclease was as noted by Little $e t$ al. (17).

Exonuclease VIII was assayed by measuring nucleotide release from ${ }^{3} \mathrm{H}$ - or ${ }^{32} \mathrm{P}$-labeled double-stranded DNA. The incubation mixture $(0.3 \mathrm{ml})$ contained $10 \mathrm{mM}$ Tris $\cdot \mathrm{HCl}$ (pH 8.0), $20 \mathrm{mM} \mathrm{MgCl}, 10 \mathrm{mM}$ 2-mercaptoethanol, $24 \mu \mathrm{M}$ labeled DNA from $E$. coli B, and enzyme [diluted immediately

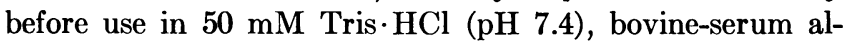
bumin $(0.5 \mathrm{mg} / \mathrm{ml})$, and $1 \mathrm{mM} 2$-mercaptoethanol]. In experiments with DNA-cellulose fractions, $0.33 \mathrm{mg}$ of bovine serum albumin was added to each incubation mixture. After incubation for $30 \mathrm{~min}$ at $37^{\circ}, 0.2 \mathrm{ml}$ of salmon sperm DNA $(2.5 \mathrm{mg} / \mathrm{ml})$ and $0.3 \mathrm{ml}$ of cold $7 \%$ perchloric acid were added. The acid-soluble supernatant fraction was counted in a toluene-Triton X-100 scintillator. One unit of exonuclease VIII is defined as that amount of protein that catalyzes the release of $1.0 \mathrm{nmole}$ of nucleotide in $30 \mathrm{~min}$ at $37^{\circ}$.

Electrophoresis in gels containing $5 \%$ acrylamide and $0.1 \%$ sodium dodecyl sulfate was performed as described by Weber and Osborn (18). Protein was determined by the method of Lowry et al. (19).

Purification of Exonuclease VIII. The $s b c A^{-}$strain, JC7693, grown in Luria broth (20), was harvested in logarithmic phase,

TABLE 2. Enzyme levels in crude extracts of $s b c A^{+}$ and sbcA9 strains*

\begin{tabular}{ccc}
\hline Genotype & $\begin{array}{c}\text { DNA polymerase I } \\
\text { (units/mg } \\
\text { of protein) }\end{array}$ & $\begin{array}{c}\text { Exonuclease III } \\
\text { (units/mg } \\
\text { of protein) }\end{array}$ \\
\hline$s b c A^{+}$ & 0.272 & 30.7 \\
$s b c A 9$ & 0.292 & 33.7 \\
$x t h A 1$ & n.t. & 3.8 \\
\hline
\end{tabular}

* Enzyme activities were assayed as described in Materials and Methods on sonically prepared crude lysates. Exonuclease III was assayed on the basis of its 3 '-phosphatase activity. Exonuclease VIII activity in crude lysates is shown in Table 1. n.t. indicates that DNA polymerase activity was not assayed in the extracts of the $x \operatorname{th} A 1$ strain. washed with $5 \%$ saline, and stored at $-20^{\circ}$ until use. All operations were carried out at $4^{\circ}$. Two hundred grams of

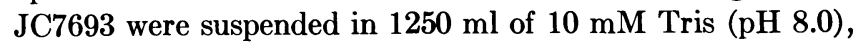
$25 \%$ sucrose $(\mathrm{w} / \mathrm{v})$, and $100 \mathrm{ml}$ of $0.1 \mathrm{M}$ EDTA. After addition of $131 \mathrm{ml}$ of egg-white lysozyme $(1 \mathrm{mg} / \mathrm{ml}$ in $10 \mathrm{mM}$ Tris $\cdot \mathrm{HCl}$, pH 7.2), $312.5 \mathrm{ml}$ of $5 \%$ Brij (in $10 \mathrm{mM}$ Tris $\cdot \mathrm{HCl}$ at $\mathrm{pH} 7.2$ ) and $1500 \mathrm{ml}$ of distilled $\mathrm{H}_{2} \mathrm{O}$ were added. The suspension was incubated for $10 \mathrm{~min}$ at $37^{\circ}$ and then held on ice for $2 \mathrm{hr}$. At this stage, $3 \mathrm{M} \mathrm{MgCl}_{2}$ was added to a final concentration of $60 \mathrm{mM}$, and the mixture was allowed to sit on ice overnight. The viscous crude lysate (fraction I, $3650 \mathrm{ml}$ ) was clarified by centrifugation for $60 \mathrm{~min}$ at $27,000 \times g$ (fraction II, $2680 \mathrm{ml}$ ).

Streptomycin sulfate $(5 \%, \mathrm{w} / \mathrm{v}$, in $10 \mathrm{mM}$ Tris, $\mathrm{pH} 8.0)$ was added to the supernatant fraction on the basis of 2.35 $\mathrm{ml} / 1000 A_{260}$ units $(265.5 \mathrm{ml})$. After the mixture was stirred for $15 \mathrm{~min}$, it was centrifuged at $27,000 \times g$ and the pellet was discarded. The supernatant fraction (fraction III) was made $50 \mathrm{mM}$ in Tris by adding $1.0 \mathrm{M}$ Tris, $\mathrm{pH} 7.5(134 \mathrm{ml})$. The solution was brought to $40 \%$ saturation by adding $731 \mathrm{~g}$ of $\left(\mathrm{NH}_{4}\right)_{2} \mathrm{SO}_{4}$. After the solution was stirred for $30 \mathrm{~min}$ it was centrifuged for $60 \mathrm{~min}$ at $27,000 \times g$. Because of the Brij-58, the majority of the protein precipitate was trapped in a detergent matrix, which layered on top of the bottles. This material, containing the bulk of the activity, was collected

TABLE 3. Fate of exonuclease III in exonuclease VIII purification procedure*

\begin{tabular}{cccccc}
\hline & \multicolumn{2}{c}{$\begin{array}{c}\text { Phosphatase } \\
\text { activity } \ddagger\end{array}$} & & \multicolumn{2}{c}{$\begin{array}{c}\text { Exonuclease } \\
\text { activity } \ddagger\end{array}$} \\
\cline { 2 - 3 } Fraction & $\begin{array}{c}\text { Specific } \\
\text { activity }\end{array}$ & $\begin{array}{c}\% \\
\text { Recovery }\end{array}$ & $\begin{array}{c}\text { Specific } \\
\text { activity }\end{array}$ & $\begin{array}{c}\% \\
\text { Recovery }\end{array}$ \\
\hline $\begin{array}{c}\text { Streptomycin } \\
\text { supernatant (III) } \dagger\end{array}$ & 8.8 & 100 & & 33.2 & 100 \\
$\begin{array}{c}\text { Ammonium sulfate } \\
\text { precipitate (IV) } \dagger\end{array}$ & 1.2 & 3.6 & & 120.2 & 74 \\
$\begin{array}{c}\text { Ammonium sulfate } \\
\text { supernatant }\end{array}$ & 17.5 & 117 & & 18.5 & 24 \\
\hline
\end{tabular}

* Small-scale purification ( $10 \mathrm{~g}$ wet weight) was carried out as described in Materials and Methods. Exonuclease III was assayed as $3^{\prime}$-phosphatase.

†raction numbers correspond to those in Table 1.

$\ddagger$ Phosphatase activity presumably indicates the presence of exonuclease III, while the exonuclease activity was determined under conditions most $f$ vorable for exonuclease VIII. 
and resuspended in $50 \mathrm{mM}$ Tris $\cdot \mathrm{HCl}(\mathrm{pH} \mathrm{7.2),} 1 \mathrm{mM}$ dithiothreitol (buffer $\mathrm{A}$ ) and clarified by centrifugation at $48,000 \times g$ (fraction IV, $202 \mathrm{ml}$ ).

The conductivity of the resuspended $\left(\mathrm{NH}_{4}\right)_{2} \mathrm{SO}_{4}$ pellet was adjusted to an equivalent of $0.15 \mathrm{M} \mathrm{NaCl}$ in buffer $\mathrm{A}$ and loaded onto a DE-52 column $(3.5 \times 23 \mathrm{~cm})$ that had been equilibrated with buffer A. A linear gradient from 0.15-0.5 M $\mathrm{NaCl}$ in buffer A (total volume, $1250 \mathrm{ml}$ ) was applied to the column. The bulk of activity eluted between 0.18 and $0.25 \mathrm{M}$ $\mathrm{NaCl}$. The peak tubes $(164 \mathrm{ml})$ were pooled and precipitated with $50 \%\left(\mathrm{NH}_{4}\right)_{2} \mathrm{SO}_{4}$. The precipitate was collected by centrifugation at $27,000 \times g$ for $15 \mathrm{~min}$ and resuspended in $0.05 \mathrm{M}$ Tris $\cdot \mathrm{HCl}(\mathrm{pH} 7.5), 1 \mathrm{mM}$ dithiothreitol, and $10 \%$ glycerol (buffer B). Fraction V $(5.4 \mathrm{ml})$ was stored in liquid nitrogen.

Two milliliters of fraction $\mathrm{V}$ were dialyzed for $2 \mathrm{hr}$ against 2 liters of buffer B and applied to a DNA-cellulose column $(3 \times$ $2 \mathrm{~cm}$ ) that had been equilibrated in the same buffer. After a 10 -ml wash with buffer $\mathrm{B}$ plus $0.05 \mathrm{M} \mathrm{NaCl}$, the column was eluted with a linear gradient from $0.05-0.35 \mathrm{M} \mathrm{NaCl}$ (total volume, $60 \mathrm{ml}$ ). The majority of activity eluted around 0.25 $\mathrm{M} \mathrm{NaCl}$. The pooled eluate was concentrated with an Amicon ultrafiltration cell. Fraction VI, representing a 750-fold purification, was stored in liquid nitrogen.

The purified fractions are relatively stable when stored in liquid nitrogen, but lose activity rapidly on repeated freezing and thawing. Unless otherwise noted, all experiments were carried out on fraction VI. An identical procedure was used for the purification from the $s b c A^{+}$strain, JC7722. A summary of two such purifications is shown in Table 1.

\section{RESULTS}

The appearance of high levels of an ATP-independent exonuclease in cells carrying $s b c A^{-}$mutations could be explained by some alteration in preexisting cellular enzymes. Modification of either the $r e c B$ and/or recC subunit could produce an enzyme of altered specificity. The fact that strains carrying $s b c A^{-}$alleles lack all the activities associated with exonuclease $\mathrm{V}$, that they carry genotypically unaltered recB21 and/or recC22 mutations, and that the $s b c A^{-}$alleles do not map in the thy $\dot{A}-\arg A$ region, tend to rule out this possibility.

Other enzymes that might be candidates for alteration include exonuclease III (14) and the 5'-3'-exonuclease activity associated with DNA polymerase I (21). Strains carrying $s b c A^{+}$or $s b c A 9$ alleles contain identical levels of DNA polymerase I and exonuclease III, as assayed in crude lysates (Table 2). When antiserum prepared against purified DNA polymerase I was added to the crude lysates, both strains exhibited a $20 \%$ decrease in double-stranded nuclease activity. Subsequent antiserum tests on fraction VI produced no effect.

In order to determine more precisely if exonuclease III might be involved, a partial purification of the ATP-independent nuclease was undertaken, with the early fractions being assayed for the specific 3 '-phosphatase associated with exonuclease III. As shown in Table 3, less than $4 \%$ of the exonuclease III activity is precipitated in the ammonium sulfate step, while most of the exonuclease activity we are following is precipitated. On the basis of these results, the nuclease appearing in $s b c A^{-}$strains was considered a new enzyme and called exonuclease VIII. It has been brought to our attention that the data are also consistent with another conclusionnamely, that the $s b c A$ mutation may affect exonuclease III such that the phosphatase and nuclease activities are sepa- rable. We will postpone dealing with this point until the Discussion.

Since the $s b c A^{-}$indirect suppressor is found in only certain genetic backgrounds (8), it has been suggested that perhaps exonuclease VIII is carried on a cryptic prophage that is derepressed during mutagenesis. Bacteriophage lambda is known to carry genetic information for an exonuclease involved in phage recombination. In order to test if exonuclease VIII might in fact be this enzyme or some closely related enzyme, fraction VI was treated with antiserum prepared against crystalline lambda exonuclease. As shown in Table 4, excess antiserum resulted in only about a $10 \%$ loss in activity. While this finding proves that exonuclease VIII is not lambda exonuclease, it does not eliminate the possibility that the enzyme is of cryptic prophage origin.

Although the results indicated that exonuclease VIII was not a modified preexisting cellular enzyme, it was of interest to determine if low levels of this activity were present in unsuppressed strains. In order to determine this, the purification procedure used for $\mathrm{JC7693}(s b c A 9)$ was carried out on $\mathrm{JC7722}$ $\left(s b c A^{+}\right)$. In Fig. 1 are shown the DEAE-cellulose elution profiles obtained from these two purifications. Fractions that eluted at the same $\mathrm{NaCl}$ concentrations as exonuclease VIII were pooled and concentrated with $\left(\mathrm{NH}_{4}\right)_{2} \mathrm{SO}_{4}$. The low level of activity present in concentrated material from JC7722 was assayed against single- and double-stranded DNA. In contrast to exonuclease VIII, which preferred double-stranded DNA by a 9 to 1 ratio at this stage, the material obtained from JC7722 showed a marked preference for single-stranded DNA.

To further corroborate this finding, the concentrated DEAE-cellulose fractions were run on $5 \%$ polyacrylamide gels containing $0.1 \%$ sodium dodecyl sulfate. A band with an $R_{f}$ of 0.33 (molecular weight, 122,000) is present in the material from the $s b c A^{-}$strain and appears to be missing in the material from the $s b c A^{+}$strain. All of the other bands appear to be present in the material from both strains, although some of them do differ in relative amounts. The DNA-cellulose fraction showed a marked enrichment for the band at $R_{f}$ of 0.33 , which, if it is exonuclease VIII; indicated a purity of approximately $50 \%$. Work by Gillen and Clark (22) indicates that the molecular weight of the native enzyme is about 130,000 .

Exonuclease VIII has an absolute requirement for $\mathrm{Mg}^{++}$, with optimal activity at $20 \mathrm{mM}$. The enzyme exhibits a $\mathrm{pH}$ optimum of 8.0 in Tris buffer. Activity on double-stranded

TABLE 4. Effect of lambda exonuclease antiserum or exonuclease VIII activity*

\begin{tabular}{ccc}
\hline & \multicolumn{2}{c}{ Activity (nmoles) } \\
\cline { 2 - 3 } Enzyme & $\begin{array}{c}\text { Without } \\
\text { antiserum }\end{array}$ & $\begin{array}{c}\text { With } \\
\text { antiserum }\end{array}$ \\
\hline Lambda exonuclease & 2.09 & 0.15 \\
Exonuclease VIII & 3.21 & 0.57 \\
& 0.15 & 0.13 \\
& 0.36 & 0.33 \\
\hline
\end{tabular}

* Identical amounts of antiserum were added to each sample, followed by incubation in the presence of substrate for $30 \mathrm{~min}$ at $37^{\circ}$. Nucleotide release was determined as described in Materials and Methods. 


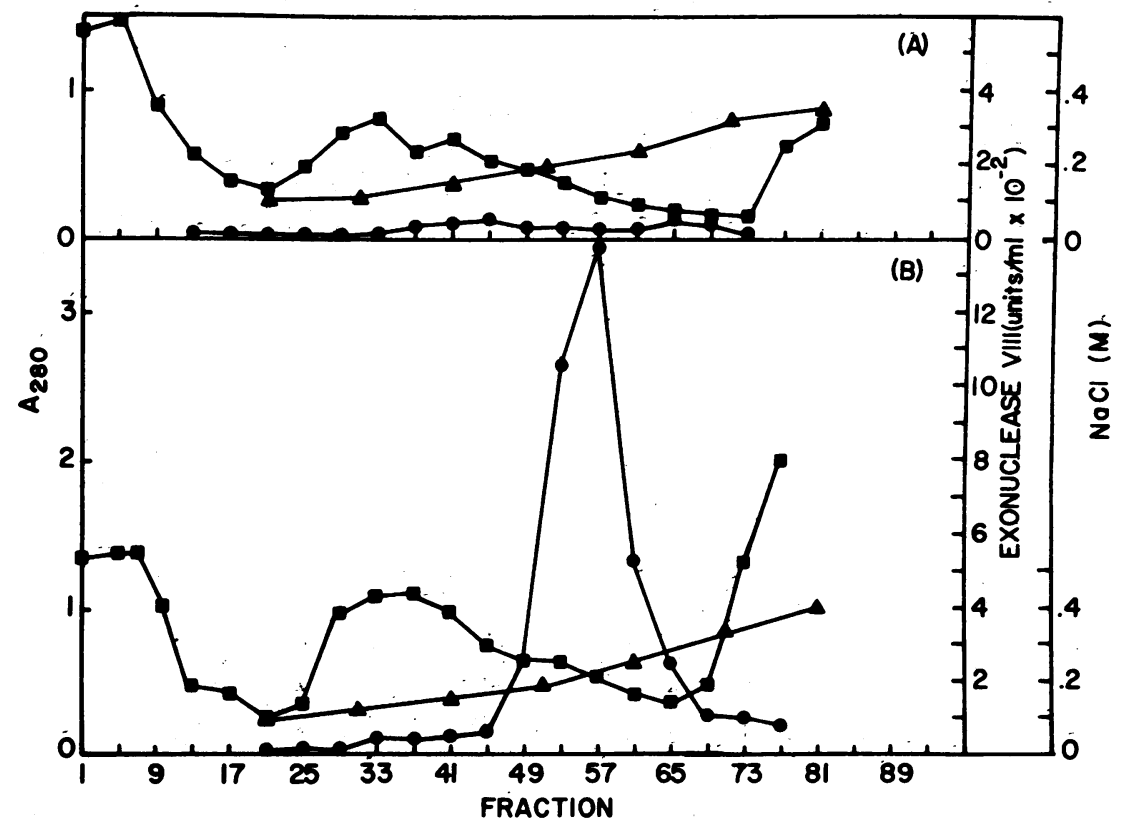

Fig. 1. DEAE-cellulose elution profiles from an $s b c A^{+}(\mathrm{A})$ and $s b c A 9$ (B) strains. Both columns were eluted as described in $M a t e r i a l s$ and Methods. $\dot{\mathbf{n}}$, Absorbance at $280 \mathrm{~nm}$; $\bullet$, activity of exonuclease VIII; $\Delta, \mathrm{NaCl}$ concentration in eluting buffer.

DNA is unaffected by addition of ATP between 20 and 200 $\mu \mathrm{M}$.

Since exonuclease VIII apparently can substitute for the multi-functional $r e c B-r e c C$ nuclease, the purified enzyme was tested for its activity on a variety of DNA substrates. As shown in Fig. 2, the enzyme shows a marked preference for native DNA over heat-denatured DNA: The relative rates varied with the preparation of heat-denatured DNA and apparently with the age of the enzyme preparation. The enzyme showed negligible activity on single-stranded, closed circular DNA in the presence or absence of ATP. This result indicates that, although not a homogeneous preparation, exonuclease VIII apparently does not exhibit the endonuclease function characteristic of exonuclease V. In addition, it seems to show a much more striking affinity for double-stranded over singlestranded DNA than is exhibited by the $r e c B-r e c C$ nuclease (6). It also contained only trace levels of 3'-DNA phosphatase. Analysis of homogeneous preparations of exonuclease VIII should serve to clarify what mode of action this enzyme uses to digest double-stranded DNA.

\section{DISCUSSION}

Loss of the recB-recC gene products results in recombination deficiency, UV sensitivity, and loss in cell viability. This enzyme is capable of digesting both single- and double-stranded DNA in the presence of ATP. It also is an ATP-stimulated, single-stranded endonuclease and a DNA-dependent ATPase (6). The presence of exonuclease VIII reverses the observed pleiotrophic effects associated with $\operatorname{rec} \vec{B}$ and/or $\operatorname{rec} C$ deficiency. From the evidence presented in this communication, exonuclease VIII appears to be a new enzyme (see below), with only an exonuclease function. While the search for intermediates involved in repair and recombination produced by exonuclease $\mathrm{V}$, the enzyme determined by $\operatorname{recB}$ and $\operatorname{rec} C$, has been hampered by the multiple catalytic activities, this problem does not seem to hold true for exonuclease VIII. A detailed analysis of the substrate specificity of exonuclease
VIII should lead to the prediction of what types of DNA intermediates may be involved in repair and recombination.

It has been shown that exonuclease VIII not only substitutes for the $r e c B-r e c C$ gene products in bacterial recombination, but also that it will completely substitute for the lambda red function (22). Since lambda exonuclease and exonuclease $\mathrm{V}$ have strikingly different substrate specificities, this finding presents an interesting paradox. The results presented here indicated that exonuclease VIII had only minor immunologic similarity with lambda exonuclease, as determined by antiserum inhibition. It is still possible that exonuclease VIII may be functionally similar to lambda exonuclease. This, if true, would also be of great interest, since the lambda enzyme has a molecular weight of 52,000 (23), while early indications point to a molecular weight of at least 122,000 for exonuclease VIII. It should be pointed out, however, that while the presence of exonuclease VIII is sufficient to allow recombination to occur in $\operatorname{rec} B$ and/or $\operatorname{rec} C$ deficient strains, the process may be entirely different from that which occurs in wild-type cells.

Although there is not direct evidence to prove whether $s b c A$ is the control gene or structural gene for exonuclease VIII, it seems most likely to be a control function. If the structural gene for the enzyme (i.e., $r e c E$ ) is carried on a cryptic prophage, $s b c A$ may in fact be similar to one of the many control genes of lambda. For the present time we prefer to think of $s b c A$ bearing a relationship to $r e c E$, the structural gene for exonuclease VIII, that lacI bears to lacZ, the structural gene for beta-galactosidase. Recent evidence of R. G. Lloyd and S. D. Barbour (submitted to Mol. Gen. Genet.) indicates that $s b c A^{+}$is dominant to $s b c A^{-}$, a result consistent with our working hypothesis.

Lloyd and Barbour also have mapped the $s b c A$ gene in the vicinity of the $x$ th gene, and it is possible that the $\operatorname{rec} E$ gene maps nearby. This is consistent with the possibility that exonuclease VIII is not a new enzyme but is exonuclease III without the phosphatase activity. We feel that this possibility 


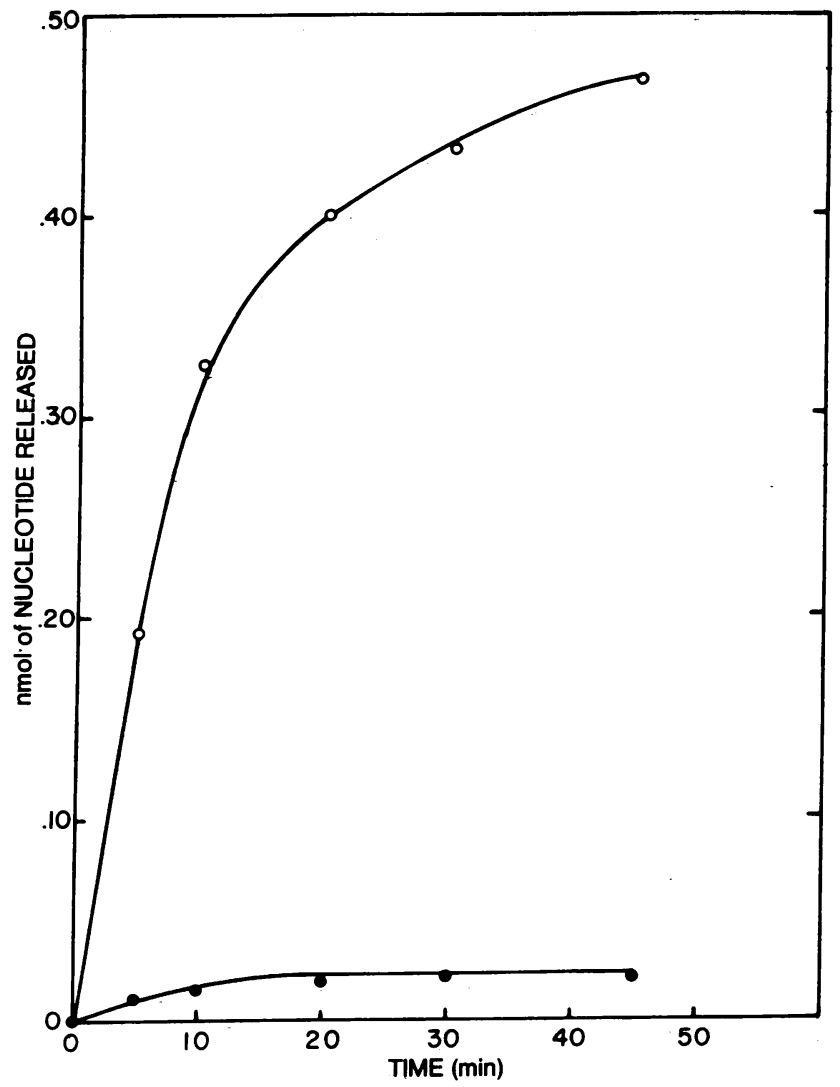

FIG. 2. Substrate specificity of exonuclease VIII. Enzyme was assayed as described in Materials and Methods, except that at time points indicated the reaction was stopped and acidsoluble radioactivity was determined. The incubation mixtures contained identical amounts of double-stranded and heatdenatured DNA. Each incubation mixture contained 3 nmoles of DNA. O, Double-stranded DNA; $\bullet$, heat-denatured DNA.

is an unlikely one, however, from what we know about the molecular weights of the two enzymes. Jovin et al. (24) have shown that exonuclease III elutes from Sephadex G-100 in such a manner that, if it were a spherical protein, it would have a molecular weight of 30,000 . If exonuclease VIII were to be this protein minus a portion that determined phosphatase activity, we would not have expected its subunit molecular weight to increase to about 120,000 , the value we have found. Because this argument is not conclusive, however, we are attempting to construct an $x t h A^{-} s b c A^{-}$strain to observe the effects on exonuclease VIII activity of a mutation inactivating exonuclease III, in the hope that this will settle the matter.

S.R.K. thanks Dr. I. R. Lehman for providing facilities for carrying out certain experiments. This work was supported in part by Public Health Service Research Grant AI-05371 from the National Institute of Allergy and Infectious Diseases and a Postdoctoral Fellowship from the National Institute of General Medical Sciences (GM-47038-03).

1. Clark, A. J. (1967) J. Cell. Physiol. 70, (Suppl. 1), 165-180

2. Low, B. (1968) Proc. Nat. Acad. Sci. USA 60, 160-167.

3. Barbour, S. D., Nagaishi, H., Templin, A. \& Clark, A. J. (1970) Proc. Nat. Acad. Sci. USA 67, 128-135.

4. Kushner, S. R., Nagaishi, H., Templin, A. \& Clark, A. J. (1971) Proc. Nat. Acad. Sci. USA 68, 824-827.

5. Horii, Z. \& Clark, A. J. (1973) J. Mol. Biol. 80, 327-344.

6. Goldmark, P. J. \& Linn, S. (1972) J. Biol. Chem. 247, 18491860.

7. Clark, A. J. (1973) Annu. Rev. Genet. 7, 67-86.

8. Templin, A., Kushner, S. R. \& Clark, A. J. (1972) Genetics 72, 205-215.

9. Milcarek, C. \& Weiss, B. (1972) J. Mol. Biol. 68, 303-318.

10. Hayes, D. H., Hayes, F. \& Guerin, M. F. (1966) J. Mol. Biol. 18, 499-515.

11. Marmur, J. (1961) J. Mol. Biol. 3, 208-218.

12. Mahler, I. (1966) in Methods in Enzymology, eds. Grossman, L. \& Moldave, K. (Academic Press, New York), Vol. 12-A, pp. 693-695.

13. Forsheit, A. B. \& Ray, D. S. (1970) Proc. Nat. Acad. Sci. USA 67, 1534-1541.

14. Richardson, C. C. \& Kornberg, A. (1964) J. Biol. Chem. 239, 242-2:51.

15. Alberts, B. \& Herrick, G. (1971) in Methods in Enzymology, eds. Grossman, L. \& Moldave, K. (Academic Press, New York), Vol. 21, pp. 198-217.

16. Richardson, C. C., Schildkraut, C. L., Aposhian, H. V. \& Kornberg, A. (1964) J. Biol. Chem. 239, 222-232.

17. Little, J. W., Lehman, I. R. \& Kaiser, A. D. (1967) J. Biol. Chem. 242, 672-678.

18. Weber, K. \& Osborn, M. (1969) J. Biol. Chem. 244, 44064412 .

19. Lowry, O. H., Rosebrough, N. J., Farr, A. L. \& Randall, R. J. (1951) J. Biol. Chem. 193, 265-278.

20. Willetts, N. S., Clark, A. J. \& Low, B. (1969) J. Bacteriol. 97, 244-249.

21. Cozzarelli, N. R., Kelley, R. B. \& Kornberg, A. (1969) $J$. Mol. Biol. 45, 513-531.

22. Gillen, J. R. \& Clark, A. J. (1974), Proceedings of Symposium on Molecular Mechanisms in Recombination, held in Gatlinburg, Tenn. April 1-4, in press.

23. Carter, D. M. \& Radding, C. M. (1971) J. Biol. Chem. 246, 2502-2512.

24. Jovin, T. M., Englund, P. T. \& Bertsch, L. L. (1969) J. Biol. Chem. 244, 2996-3008. 